\title{
The Impact of Leadership Styles on Selection the Areas of Organizational Change (An Empirical Study on the Jordanian Pharmaceutical Companies)
}

\author{
Salah M. Diab ${ }^{1}$ \\ ${ }^{1}$ Business Administration Department, Economics and Admin. Faculty, Applied Science University, Amman, \\ Jordan \\ Correspondence: Salah M. Diab, Business Administration Department, Economics and Admin. Faculty, Applied \\ Science University, Amman, Jordan. E-mail: salahdiab2002@yahoo.com
}

Received: April 22, 2014

doi:10.5539/ijbm.v9n8p140
Accepted: June 4, 2014

Online Published: July 25, 2014

URL: http://dx.doi.org/10.5539/ijbm.v9n8p140

\begin{abstract}
The purpose of this study is to test The Impact of Leadership Styles on the Organizational Change Areas (An Empirical Study on the Jordanian Pharmaceutical Companies). Data for this research were collected through a questionnaire from, (240) leaders in all levels of management, from (5) pharmaceutical companies in Jordan, which are; (JPHM), (DADI), (HIKMA), (ACPH), and the (PIC). Grynbach constancy coefficients reached $84.0 \%$, Percentages, Means, standard deviation, and, simple and multiple regressions analysis s were used to test the hypothesized relationships. The results indicate that, The Jordanian pharmaceutical companies (JPCs) practiced both types transformational and Transactional leadership, in different proportions. All the organizational change areas in the (JPCs) are possible, a strongly positive relationship between styles of leadership (transformational and Transactional) combined and the organizational change areas, Inspiration as one of the Transformational leadership elements is the less influential ,in addition to that there's a variation impact on the organizational change areas for all the leader ship styles elements, transformational leadership does not affect on changes in human resources and job description, On the light of the study results the following recommendations may be submitted, More attention to the transformational leadership style to bring a long-term organizational change, without depends only on the transactional leadership, specially the incentive element, increased the enrichment knowledge of the departments leader through involvement in academic courses Encourage leaders, who have the qualities and skills possessed by transformational leadership style for the assumption Managerial positions in the (JPHs) and other recommendations.
\end{abstract}

Keywords: the Jordanian pharmaceutical companies, organizational change areas, styles of leadership (transformational and transactional)

\section{Introduction}

The process of organizational change considered as a positive phenomenon, it may be used by most of the organizations for the aims of innovation, development, and to be still in good position in the labor market, which made a lot of interested people and researchers to focus on the organization and organizational behavior as well as a focus on organizational change, and many other related topics.

The literature Administration has focused on different sets of areas of organizational change in this study it will be adoption of the technology, change in the organizational structure, and the change in human resources needs, and Job Description.

In contrast, the Leadership Style followed and adopted by the various administrative levels in the managing of business organizations different from organization to other in light of a lot of factors and variables that are related to the nature of the work of those organizations (Kezar, 2011, p. 485).

In addition to that the administrative literatures focused on different types of leadership styles, in this study the Researcher will considered the following leadership styles: transformational and transactional leadership style (Harris, 2012, p. 10).

In this empirical study the researcher want to conduct the views of administrative leadership at various levels in 
the Jordanian Pharmaceutical Companies to show the extent of the impact of the use of leadership styles (transformational and transactional leadership style) on the areas of the organizational changes (change in technology, change in the organizational structure, and change in human resources needs and Job Description) in the Jordanian pharmaceutical companies.

In addition to the researcher desire to know which styles of leadership are the most commonly used by the leaders of the Jordanian pharmaceutical companies in various management levels, and which style is the most influential in organizational changing?

\section{Literature Review}

\subsection{Leadership}

The leadership represents an important focus in the administrative process; it is affected in workers to make them more committed to accomplish what is required of them. The leadership focuses on pushed the workers to use their skills and abilities in the implementation of activities to achieve the organization goals through effective leadership that affect their behavior and cause them willing to work (Bass, 1985, p. 287).

many administrative books talk about the difference between management and leadership, where as the leadership focus on the influence on behavior of others, Thiers more than one method to influencing in the behavior of the employees as the following: consultation, persuasion rational appeal suggestive (address the emotions), tactics gain satisfaction and flattery, the tactics of the coalition , or the exercise of pressure and threats, the Supreme Administrative support levels, as well as the exchange of interests and benefits. In addition to that, there are many divided to leadership styles, such as; bureaucracy, democracy, participative, consultant, and lazesfair. And other divisions of modern leadership, in this study the researcher will consider the divided leadership style (transactional leadership and transformational leadership) (Agashae, 2001, p. 95).

\subsection{Leadership Styles}

\subsubsection{Transactional Leadership}

In the transactional leadership, the commander swap efforts by workers to achieve the goals of the organization by paying an incentives whether a fee or moral, this leadership style directed the efforts of workers through bonuses, incentives, training, and organizational structure positions.

Therefore, this style of leadership cares to clarify the roles, tasks , and duties assigned to subordinates as well as build relationships enhance work with subordinates so the transactional leadership has the ability to satisfy the subordinates as an introduction to improve productivity and services and it is a perseverance, tolerant, understanding, and good and fair mentality.

Its emphasizes the manifestations in the personal leadership ,such as , plans efficient, scheduling, and corrected budgets in addition to that, this style of leadership desire to generate commitment with norms, and organizational value (Ameri \& Galbi, 2008, 220).

(Brown \& Dodd, 1999), Confirms that the Transactional leader requires from him to search for any deviation in the application of the regulations to take corrective action necessary, this will increases the leader influence in the behavior of subordinates during this follow-up.

\subsubsection{Transactional Leadership Elements}

There are many elements of the Transactional leadership, in this study, it will adopted of two key elements:

\section{- Incentives}

Financial rewards paid to workers whose production exceeds some predetermined standards, this pay may be according to piece work, or variable pay, its depend on many factors related to the nature of the organization, and the type of the standards applied, the incentives is very span topic you may look as reference to any human recourses book such as our reference (Dessler, 2008, p. 480).

\section{- $\quad$ Training}

It's the process of teaching new employees the basic skills they need to perform their jobs, and learned the old employees the new procedures and technology or any new thing that the organizations introduced. There are many steps for training, determined the needs, introduced design, validation, implementation, and evaluation, and there are many methods and procedures for training. Any way the managers in the organization take decision about the, steps, topics, and strategy applied in training in their organization depending on their own factors (Dessler, 2008, p. 311). 


\subsubsection{Transformational Leadership}

It is based on leading the workers to teach more than expected to achieve high level goals, this requires finding a newer vision for the future of the organization as a whole, in addition to the events of change and leadership in an orderly fashion, especially in light of fierce competition (Zearah, 2009, p. 359).

(Charbonnea, 2004, p. 185) refers that transformational leadership is a minimal impact for the leader on his subordinates to transcend for their own interests for the benefit of the organization. transformational leadership has a great ability to give the impression of subordinates to do the best they could for their efforts on behalf of the organization and has a high capacity to effect change and achieve creativity by organizing the needs of subordinates and their interests and help them use new ways to solve old problems, and encourage them to discuss the current state always, he has the ability to change the mission and strategy of the organization.

(Abdel-Maksoud, 2006, p. 20) considered transformational leadership is a style of leading has a clear vision for the future and specific goals and encourages subordinates to participate in the vision and objectives and adopt a flexible style of leadership being able to adopted with variables and are working together.

\subsubsection{Elements of Transformational Leadership}

\subsubsection{Charisma}

the leader find a clear organizational vision and make others follow this vision ,this reflects the strength of character that occur high degree of loyalty, commitment and recognition of the leader, as well as the subordinate must be open-minded, the leaders charisma are characterized by strongly personal and self-confidence and tact and emotional expression, as well as their tendency to accept risk (Daft, 2003, p. 268).

(Faculty. Ksu. Edu) See that the effect of charisma means finding the leader with a clear vision and a sense of supreme mission of the organization and the development of trust and respect with followers.

It also describes the behavior of a leader who admired and appreciated and respected personnel and requires participation in risk by providing the needs of the leader and follower before his personal needs and does the actions of a moral nature (www.arabfylle.net).

\subsubsection{Inspiration}

Reflect the actions and behavior of the leader, which raises the follower love the challenge and the ability to clarify expectations and deliver them, inspiration describes the style of commitment to organizational goals and raise team spirit through the enthusiasm and idealism (www.arabsystem.net).

\subsubsection{Intellectual Stimulation}

The transformative leader search on the new ideas which raises followers to see the problems and encourage them to provide possible solutions and creative ways to support new and innovative models to perform the work. Transformative leaders determine the purpose, threats, strengths, and weaknesses of the organization (Kenny, 1994, 397).

\subsubsection{Individualized Consideration}

the leader concerns in terms of the feelings of his followers encouragement and guidance, advice and listen to them and attention to their needs and their achievements through the adoption of strategies appreciation, flattery and the adoption of open communication with them and work hard to assign individuals who deserve it . For the purpose of staff development is supposed leader transformational not treated the same level because they are in different qualities and the ability to conduct and performance of the actor. (Allen, 2004.36-39)

\subsection{Organizational Change}

The literature focused on the importance of change in organizations and its positive role in the development of these organizations (Crawfod, 2005, p. 16) defined the organizational change as a management style whereby transforming the organization from its current state to the most efficient among its expected future. (Hrrsey, 1996, p. 88) has defined the organizational change, as the organization's ability to adapt to environmental changes. (Hellrieged, 2001, p. 152) defined organizational change as the organization's response to environmental changes that the organization faced to achieve better alignment and the faster response. (Astly, 1984, p. 139) defined it as a sophisticated strategy for education aims to change attitudes and values and organizational structure to fit with modern trends and be able to cope with environmental variables of the organization. (Ameri, 2008 , p. 423) it is considered organizational change as a fundamental adjustment substantially in some parts of the organization or all of them. He adds (Ameri, 2008, p. 440 ) that the forces of change in the organization can be from inside such as activities ,tasks and duties, either external forces for change in the organization, such as 
consumers and competitors, technology and economic aspects, social and political. Thus, to introduce any element of the powers referred to the change power (internal or external) the change in the organizations will happened.

The organizational change areas (Baron, 1990, p. 98), identified four major areas of changes in the organization which are: -technological and operation change, organizational structure change, human resources needs change, and job descriptions change-in this study job description and human resources as a one variable, thus became the areas of changes in the organization are three: Technological change, organizational structure change, human resources needs change and job descriptions change.

\subsubsection{Technological Changes}

Include changes that can take place in any organization in the areas of production or productivity, or the way of skills and abilities that are handled by the organization with the technology or working methods, machinery and equipment (Moorhead, 1995, 75). It also could include a change in the technology systems used and controller methods, or the change in the product itself.

\subsubsection{Change in Organizational Structure}

it connected with the process of change in the organizational structure in the re- distribution of administrative units by jurisdiction or by tasks per unit in addition to the re- design of lines and channels of communication between the administrative units in addition to the possibility of creating or delete any administrative unit within the organizational structure (Hickson, 1991, p. 105). The change in the organizational structure could include the distribution of powers and methods of coordination and management of human resources so as to change the criteria for selecting individuals and evaluate performance, these changes may include the objectives and characteristics of the organizational structure and procedures and administrative systems (Ameri, 2005, 428).

\subsubsection{Change in Human Resources and Job Description}

its includes the changes in skills, experience and cognitive abilities, and behaviors in addition to re- formation of new positive values and attitudes in order to achieve the objectives of the organization (Gibson, 2003, p. 177-179). The change may be either in the type of human resources or in its number (increase or decrease), and also includes training and incentives systems and special instructions, it also could include a change in the perception and expectations of individuals in the organization in addition to the change in the development of new business or leave the work list, or change in the style of the current work according to the needs of the organization (Hughes, 2009, p. 119).

\section{Previous Studies}

The studies in the areas of leadership styles and it affecting on the organizational change are limited, there's a lot of studies related to leadership styles and several studies focused on organizational change, the studies that were relevant to this topic are:

Studies of (Tahan, 2000), "The impact of leadership styles on the satisfaction of employees and administrative creativity-an exploratory study of joint stock companies in Jordan." The study found a strong correlation between leadership styles and administrative innovations.

Studies of (Alkshali, 2003), "the impact of leadership styles of the heads of scientific departments on organizational loyalty members of teaching in Jordanian private universities." The study showed a negative relationship between leadership style autocratic and between all the dimensions of organizational loyalty In contrast, a positive relationship between organizational loyalty and leadership style democratic in its various dimensions.

Studies of (Alkhshali, Jarallah, Tamimi, Fadel, 2008), "the impact of the methods of leadership in organizational learning - a study on Jordanian industrial companies ".it found that the companies having a significant effect for style of transactional leadership and manufacturing in organizational learning quality in both type adaptive and generative.

Studies of (Aljamaan, saleh 2009) "The impact of leadership style on organizational affiliation an empirical study on employees in business firms in Saudi Arabia". The study concluded that there is affect of transformational leadership (all its dimensions) and are extrusive in increasing organizational affiliation of the employees in business firms in Saudi Arabia .

Studies of (Silyman \& Azzazi, 2010), "the impact of the dimensions of transformational leadership in the management of organizational change - a prospective study of the views of a group of heads of departments at Waladyha in Mosul/Iraq "The study found insufficient organizational changes without existence transformational 
leadership in that organizations, as well as the study created appositive relationships between the dimensions of transformational leadership and the organizational changes.

Studies of (Husseini \& Bushra, 2010), "The impact of the transformational and the transactional leadership styles on the success of the Organizational changes-an empirical study in the General Company for Electrical Industries " the study found the existence of a positive relationship between leadership styles and organizational change, and that the leadership of the company in question pay attention variable leadership of transactional rather than transformational leadership.

studes of (Khroukh \& Raghad, 2010), "about the strength of leadership tool to support the areas of organizational change - a prospective study of the views of a sample of administrative leaders in some of the industrial organizations in Nineveh province in Iraq", the study found the presence of the leaders ability to change the regulatory areas in addressed companies, the study also showed a positive relationship between the power sources of leadership and the areas of organizational change, as well as a positive relationship between each dimension of the power sources of leadership and the organizational change areas.

studies of (Hammad \& Iyad, 2011) "The impact of transformational leadership in change management - a field study on hospital Red Crescent in Damascus" the study found theirs a transformational leadership effected on the process of change management within the Red Crescent hospital in Damascus, and all the dimensions of transformational leadership has the same impact on organizational change management.

\section{Study Objectives}

This study aims to achieve the following:

To answer questions the justification for the study described below.

Test and measurement of the impact of the leadership styles used on the possible areas of organizational change in the Jordanian pharmaceutical companies.

To know which leadership styles (transformational, or/and transactional) used to change one or more of the areas of organizational changes (change in technology, change in organizational structure, change in human resources and Job Description) in Jordanian pharmaceutical companies, and, which of these patterns are the most commonly.

Make appropriate recommendations in the light of the results of this study.

\section{The Rational and Problem of the Research}

The rational and Problem of this study Summarized in a range of questions, which are:

- Is there a clear perception among leaders at various levels in the Jordanian pharmaceutical companies about the concept and the types of leadership styles, and which one of those leadership styles actually used?

- What islare the perceptions of the administrative leaders in the Jordanian pharmaceutical companies about the concept and the types of organizational change areas, and what are the areas that can be applied in the Jordanian pharmaceutical companies?

- is there an impact or relations between the leadership styles used and the possible organizational change areas in the Jordanian pharmaceutical companies?

\section{Framework and Research Hypothesis}

\subsection{Research Framework}

The proposed framework for this research is illustrated in Figure 1. The framework shows the impact of leadership styles (transformational, land transactional) on the Organizational Change Areas. 


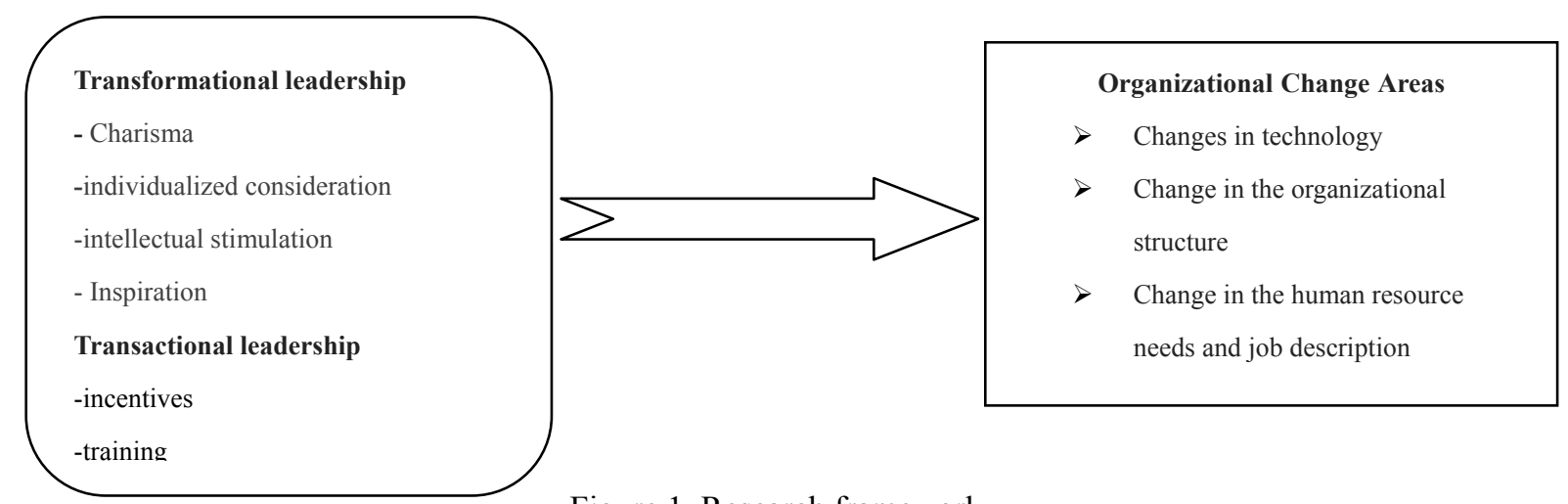

Figure 1. Research framework

\subsection{Research Hypothesis}

\subsubsection{First Hypothesis}

H0: There is no correlation between the leadership styles together (Transformational, Transactional) and the Organizational change areas.

H1: There is a correlation between the leadership styles together (Transformational, Transactional) and the Organizational change areas.

\subsubsection{Second Hypothesis}

H0: There is no impact of the elements of Transactional leadership (incentives and training) and transformational leadership (Charisma, individualized consideration, intellectual stimulation, and Inspiration) on the organizational change (combined areas).

H1: There is an impact of the elements of Transactional leadership (incentives and training) and transformational leadership (Charisma, individualized consideration, intellectual stimulation, and Inspiration) on the organizational change (combined areas).

\subsubsection{Third Hypothesis}

H0: There is no impact of the elements of the transformational and Transactional leadership (combined) or (separately) on the organizational change areas (Changes in technology, organizational structure, and human resource needs and job description).

H1: There is no impact of the elements of the transformational and Transactional leadership (combined) or (separately) on the organizational change areas (Changes in technology, organizational structure, and human resource needs and job description).

\section{Methods and Procedures}

\subsection{Study's Methodology}

To build a theoretical framework through different sources of books and scientific journals, and the Internet. The preliminary data will be obtained through a questionnaire design consists of two sets of questions, first group leadership styles adopted in this study, while the second group organizational change areas.

\subsection{Study's Population and Sample}

Study's population consists of all the leaders in the pharmaceutical companies in Jordan, since a questionnaire will be distributed a sample consisting of (240) leader from all levels of management, Take in our consideration that there are (17) pharmaceutical companies in Jordan with around (2000) leader in different levels, the representative companies are (5), which are:

Jordanian pharmaceutical of medicines (JPHM), Dar Al Dawa for Development and Investment (DADI), Hikma Pharmaceutical Company(HIKMA), Arab Company for pharmaceutical(ACPH), and the pharma international company(PIC).

\subsection{Data Collection Methods}

The main instrument of this study relays on the questionnaire, it was developed in the front of a questionnaire after reviewing previous studies in this field it consisted of two parts: 
- $\quad$ Preliminary data including (Age, Gender, social status, etc.).

- Measuring the variables of the study (leadership styles, and organizational changes areas).

This part was designed according to likart scale, and consists of (50) clauses with the answers (strongly disagree, disagree, don't know, agree, strongly agree,), given the weights $(1,2,3,4,5)$. The higher the mean, indicates to higher degree of consent on the clause.

\subsection{Internal Consistency}

Grynbach Alpha confections were obtained for internal consistency between the clauses attitudes scale, as Grynbach coefficients reached $84.0 \%$, and it is a high value that indicates to the study's instrument constancy.

\subsection{Statistical Methods Used}

The following statistical methods used for statement attributes the study sample and examine hypotheses:

-Frequencies and percentages for the distribution of the demographic characteristics of a statement of the study sample.

-Means and to identify the extent of the use patterns of the leadership styles and organizational change areas, and the standard deviation to measure the degree of dispersion in the values of responses of the sample around the areas of leadership styles and organizational change.

-Using regression analysis to identify the extent of the impact of leadership styles on the areas of organizational change.

\section{Results and Testing Research Hypothesis}

Table 1 appears that (50\%) percentage of sample are middle level leaders, the higher percentage (56\%) are female, the greater percentage (46\%) form those age between (31-45) years old, It is also noticed that the higher percentage (73\%) married,(36\%) of the study sample has (11-15) years experience, notes that (18\%) has (16)year experience and more, The higher percentage (74\%) has Bachelor degree.

Table 1. General characteristics of the study sample individuals

\begin{tabular}{|c|c|c|c|}
\hline Job & Sample No & Total & Percentage \\
\hline JOB & & 240 & $100 \%$ \\
\hline High level leaders & 40 & & $17 \%$ \\
\hline Mid. level leaders & 120 & & $50 \%$ \\
\hline Low level leaders & 80 & & $33 \%$ \\
\hline GENDER & & 240 & $100 \%$ \\
\hline Male & 105 & & $44 \%$ \\
\hline Female & 135 & & $56 \%$ \\
\hline AGE & & 240 & $100 \%$ \\
\hline Less than 30 years & 25 & & $10 \%$ \\
\hline 31-45years & 110 & & $46 \%$ \\
\hline $46-55$ years & 75 & & $31 \%$ \\
\hline 56 years -and above & 30 & & $13 \%$ \\
\hline SOCIAL STATUS & & 240 & $100 \%$ \\
\hline Married & 176 & & $73 \%$ \\
\hline Single & 54 & & $23 \%$ \\
\hline Divorced / Widowed & 10 & & $4 \%$ \\
\hline EXPERIENCE & & 240 & $100 \%$ \\
\hline 1-5 Years & 32 & & $13 \%$ \\
\hline 6-10 Years & 80 & & $33 \%$ \\
\hline $11-15$ year & 86 & & $36 \%$ \\
\hline
\end{tabular}




\begin{tabular}{|c|c|c|c|}
\hline 16 years and more & 42 & & $18 \%$ \\
\hline QUALIFICATION & & 240 & $100 \%$ \\
\hline BA/Bachelor & 178 & & $74 \%$ \\
\hline MA/ Master & 47 & & $20 \%$ \\
\hline $\mathrm{PhD} /$ Medical board & 15 & & $6 \%$ \\
\hline
\end{tabular}

Arithmetic means extracted, In order to see the practice of leadership styles in Jordanian pharmaceutical companies (JPCs), and the possibility of organizational change areas (one or more) as in Table 2.

Table 2. The mean and standard deviation for the study sample answers about leader ship styles and organizational change areas

\begin{tabular}{lll}
\hline & MEAN & STD. Deviation \\
\hline Ttransactional Leadership (Ta.L) & 4.10 & 0.607 \\
T.L. elements: -Incentives & 4.21 & 0.648 \\
-Training & 4.11 & 0.566 \\
Transformational Leadership(Tf.L) & 3.20 & 0.508 \\
Tf.L.elements:- Charisma & 3.18 & 0.512 \\
-Intellectual stimulation & 3.88 & 0.479 \\
-Inspiration & 3.22 & 0.438 \\
-individualized consideration & 4.20 & 0.610 \\
Organizational. Changes & 3.34 & 0.456 \\
Technological changes & 4.12 & 0.364 \\
Change in organizational structure & 3.10 & 0.428 \\
Change in human resources and job description & 2.80 & 0.579 \\
\hline
\end{tabular}

This Table 2 shows that these (JPCs) exercised both types of leadership styles; transformational and transactional leadership, with means (3.10), (4.20), according to the mean the used of transactional leadership is greater than the other, about all the element of leadership (transformational and transactional), incentives the most commonly used ,it's the higher mean (4.21), the possible organizational change areas of (JPCs),has reached (3.34) which means there's a possible for change, technological changes is the most possibility with mean (4.12), While the change in human resources was difficult which shows(2.80), which less than (3).

Table 3. Pearson correlation of the relationship between transformational and transactional leadership with organizational change areas

\begin{tabular}{lllll}
\hline $\begin{array}{l}\text { Organizational. } \\
\text { Changes }\end{array}$ & Leadership styles:- & $\begin{array}{l}\text { Transformational Leadership } \\
\text { (Tf.L) }\end{array}$ & $\begin{array}{l}\text { Ttransactional } \\
\text { Leadership (Ta.L) }\end{array}$ & \\
\hline 0.588 & - & - & 1 & $\begin{array}{l}\text { Ttransactional } \\
\text { Leadership (Ta.L) } \\
0.601\end{array}$ \\
& - & 1 & - & Transformational \\
0.595 & 1 & - & - & Leadership (Tf.L) \\
1 & 0.595 & 0.601 & 0.588 & Leadership styles \\
& & & & Organizational \\
\end{tabular}

Note. correlation significant at the $0.01(2$-tailed).

Table 3 shows that there is a relationship between transformational and transactional leadership together with 
organizational change areas, with Pearson correlation (0.595), but the correlation between transformational leadership with organizational change areas $(0.601)$ is greater than the correlation with transactional leadership (0.588).

These results confirm the rejection of the null hypothesis and accept the alternative hypothesis that there is a correlation between the transformational and transactional leadership and organizational change areas. The result of the multiple linear regression analysis tables (4) related to the second hypothesis, shows that there is an impact of the elements of transformational and transactional leadership on the organizational change areas (combined), and this impact varied from element to another, Incentive as one of the Transactional leadership elements is the most influential where (B) (0.49), and (t) value (6.01) with (0.000) significance, this result explain (44\%) from the organizational change areas. On the other hand Inspiration as one of the Transformational leadership elements is the less influential where (B) $(0.22)$, and (t) value (2.16) with (0.030) significance, this result explain $(22 \%)$.

Table 4. Multiple linear regression analysis of the impact of the elements of transformational and transactional leadership on the organizational change areas (combined)

\begin{tabular}{llllll}
\hline & $\mathrm{B}$ & $\mathrm{T}$ & $\mathrm{Sig}$ & $\mathrm{R} 2$ & $\mathrm{~F}$ \\
\hline (Ta.L). elements: -Incentives & 0.49 & 6.01 & 0.000 & 0.44 & 49.68 \\
-Training & 0.30 & 2.42 & 0.000 & 0.29 & 30.21 \\
(Tf.L). elements: -Charisma & 0.25 & 2.96 & 0.002 & 0.25 & 20.60 \\
-Intellectual stimulation & 0.40 & 3.54 & 0.000 & 0.40 & 25.22 \\
-Inspiration & 0.22 & 2.16 & 0.030 & 0.20 & 15.17 \\
-individualized consideration & 0.29 & 2.93 & 0.002 & 0.30 & 21.66 \\
\hline
\end{tabular}

Table 4 also shows theirs a variation impact on the organizational change areas for all the leader ship styles elements, can be arranged in descending order according to the degree of influence as follows; Incentive, intellectual stimulation, training, individualized consideration, Charisma, Inspiration. On the light of this results we rejected the null hypothesis and accept the alternative hypothesis, there is an impact of the elements of Transactional leadership (incentives and training) and transformational leadership (Charisma, individualized consideration, intellectual stimulation, and Inspiration) on the organizational change (combined areas).

The results in Table 5 shows that transformational leadership does not affect on changes in human resources and job description where (B) is $(0.017),(\mathrm{T})$ value $(0.031)$ with $(0.065)$ significance, on the other hand theirs a transformational leadership impact on technology Changes, where $(\mathrm{B})$ is $(0.53),(\mathrm{T})$ value $(7.26)$ with $(0.000)$ significance, and organizational structure changes, where $(B)$ is $(0.40),(T)$ value $(4.21)$ with $(0.000)$ significance.

Table 5. Multiple linear regression analysis of the impact of leadership styles (combined) on the organizational change areas

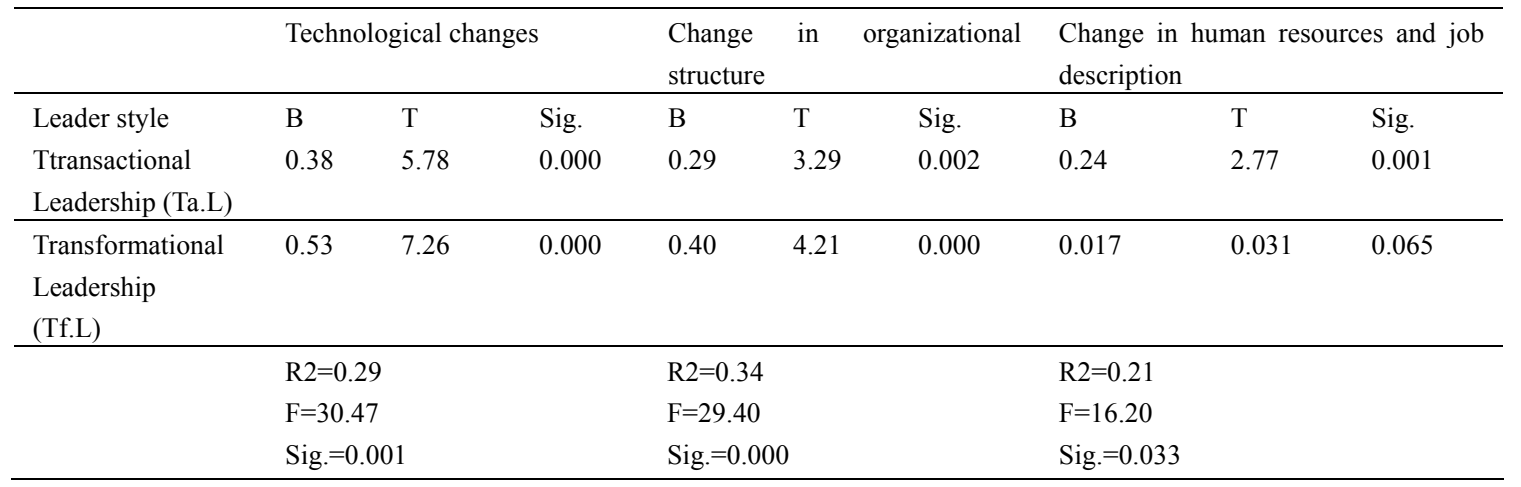

The Transactional leadership has also an impact on all the organizational changes areas, technology, where (B) is 
(0.38), (T) value (5.87) with (0.000) significance, organizational structure where (B) is (0.29), (T) value (3.29) with $(0.002)$ significance, human resource needs and job description where $(\mathrm{B})$ is $(0.24)$, $(\mathrm{T})$ value $(2.77)$ with (0.001) significance, on the light of this results we reject the null hypotheses and accept the alternative, There is an impact of the elements of the transformational and Transactional leadership (combined) on the organizational change areas (Changes in technology, organizational structure, and human resource needs and job description),except the non impact of the Transactional leadership on the change of human resource needs and job description.

Table 6. Correlations between the elements of leadership styles (Transactional and transformational separately) and each organizational change areas

\begin{tabular}{lllll}
\hline Leadership styles & Leadership elements & $\begin{array}{l}\text { Technological } \\
\text { changes }\end{array}$ & $\begin{array}{l}\text { Change } \\
\text { organizational } \\
\text { structure }\end{array}$ & $\begin{array}{l}\text { in } \\
\text { Change in human resources } \\
\text { and job description }\end{array}$ \\
\hline Ttransactional & Incentives & 0.808 & 0.741 & 0.874 \\
Leadership (Ta.L) & Training & 0.832 & 0.643 & 0.885 \\
\hline & Charisma & 0.800 & 0.394 & 0.103 \\
Transformational & Intellectual stimulation & 0.576 & 0.425 & 0.134 \\
Leadership & Inspiration & 0.461 & 0.610 & 0.122 \\
(Tf.L) & individualized & 0.605 & 0.819 & 0.110 \\
& consideration & & 0.4540 & 0.465 \\
\hline Total indicators & & 0.693 & 0.631 & 0.411 \\
\hline
\end{tabular}

Table 6 shows the impact of each leadership styles element (Transactional and transformational separately) on the organizational change areas, the most correlation between training and the Changes in the human resource needs and job description (0.885), then the incentives with Changes in the human resource needs $(0.874)$, on the other hand the most less correlation between Charisma and Changes in the human resource needs $(0.103)$.

\section{Conclusions and Recommendations}

\subsection{Conclusions of This Study Showed the Following}

The Jordanian pharmaceutical companies (JPCs) practiced both types transformational and Transactional leadership, but in different proportions, (JPCs) used Transactional leadership more than transformational leadership.

All the organizational change areas in the (JPCs) are possible, with average (3.34), but the change in technology is the most likely with average (4.12) and the change in human resources is the least possibility (2.80).

The study shows a strongly positive relationship between styles of leadership (transformational and Transactional) combined and the organizational change areas in (JPCs), where the correlation (0.595), but the relationship between the organizational change areas and Transactional leadership) (0.788) is more strength than the relationship with transformational leadership (0.601).

There is an impact of the elements of transformational and transactional leadership on the organizational change areas (combined), this impact varied from element to another, the Incentive as one of the Transactional leadership elements Is the most influential, Inspiration as one of the Transformational leadership elements is the less influential, in addition to that there's a variation impact on the organizational change areas for all the leader ship styles elements, can be arranged in descending order according to the degree of influence as follows; Incentive, intellectual stimulation, training, individualized consideration, Charisma, Inspiration.

The study shows that transformational leadership does not affect on changes in human resources and job description, but there's an impact on Changing technology, and organizational structure changes.

The Transactional leadership has an impact on all the organizational changes areas. On the other hand theirs an impact of each leadership styles element (Transactional and transformational) on the organizational change areas, the most impact training on the Changes in the human resource needs and job description, but the most less impact Charisma on Changes in human resource needs.

\subsection{Recommendations of This Study as the Following}

On the light of the study results the researcher recommends the following: 
More attention to the transformational leadership style to bring a long-term organizational change, without depends only on the transactional leadership, specially the incentive element.

The Jordanian pharmaceutical companies are working to increased the enrichment knowledge of the departments leader through involvement in academic courses, seminars and specialized (inside and outside the country) for the purpose of Inform them of the latest developments that occur on the leadership styles of contemporary, which supports their ability to change and development.

Encourage leaders, who have the qualities and skills possessed by transformational leadership style for the assumption Managerial positions in the (JPHs).

The change Must stems from the needs, which produced by the environmental conditions and the need for target markets, not be lifted to chance and improvisation.

The Jordanian pharmaceutical companies must provide financial and material capabilities to keep up with the technology and work on the rehabilitation of individuals working on the use and develop their skills to match the happening and expected Technological changes.

Further studies on the organizational change areas and leadership styles in various organizations (service and productive org).

\subsection{Analyses Result}

the results of this study, consistent with the results of some other studies that dealt with this subject such as (Hammad, Iyad, 2011), this study shows that there is a relative relationship between organizational change and transformational leadership in the Red Crescent Hospital in Damascus, Syria, as well as convergence in the results with (Salman Majid al-Azzawi Mohammed ,2010), al-Azzawi study showed, a strong correlation between the transformational leadership and management of organizational change in the coefficient of clothes at birth in Mosul, Iraq, as well as harmony with the results of (Husseini, Bushra) study, which showed the existence of a positive relationship between leadership styles and organizational change, and that the leadership of the company in question pay attention variable leadership of transactional rather than transformational leadership, in addition to (Raghad, Khroukh, 2010), study which shows a relation between power and leadership styles in organizational change areas, in some organizations industries in Iraq.

This study did not find a correlation between transformational leadership and change in the field of human resource management.

\section{Acknowledgement}

The Author is Grateful to The Applied Science University, Amman, Jordan for the Full Financial Support Granted to This Research Project (Grant No.BI 35 )

\section{References}

Abdel, M. M. (2006). Managereal Leadorshep. Arab Commsmfy Instituie, Jordan: Amman.

Agashae, Z., \& Bratton, J. (2001). Leader-Follower Dynamics: Developing A learning Environment. Journal of Workplace Learning, 13(3), 89-102. http://dx.doi.org/10.1108/13665620110388398

Aljamaan, S. (2009). The Impact of Leadership Style on Organizational Affiliation an Empirical Study on Employees in Business Firms in Saudi Arabia, Ph.D. thesis. Ain Shams University, Faculty of Commerce and Business Administration.

Alkhshali, J., \& Tamimi, F. (2008). The Iimpact of the Methods of Leadership in Organizational Learning-A study on Jordanian Industrial Companies. Jordan Journal of Business Administration, 4(2).

Alkshali, S. (2003). The Impact of Leadership Styles of the Heads of Scientific Departments on Organizational Lloyalty Members of Teaching in Jordanian Private Universities. Jordan Journal of Applied Science, 6(1).

Allen, G. A., \& Plunkett, W. R. (2002). Management: Meeting, and Exceeding Customer Expectation (7th ed.). NewYork, U.S.A: south-western publications Co.

Ameri, S., \& Galbi, T. (2008). Business Administration (2nd ed.). Wail publication Co., Amman, Jordan.

Astly, W., \& Socher P. (1984). Structural Sources of Inter-organizational Power. Academy Of Management Review, 9.

Baron, R. A., \& Green, B. J. (1990). Behavior in organization understanding and Managing the Human side of work (3rd ed.). New York: McGraw-hill book Co. 
Bass, B. (1985). Leadership and Performance Beyond Expectation. New York, NY: The Free Press.

Bass, B., \& Avolio, B. (1990). Multifactor Leadership Questionnaire. Consulting Psychologists Press.

Brown, F., \& Dodd, N. (1999). Rally the Troops or Make Train run on Time: The Relative Importance and Interaction of Contingent Reward and Transformational Leadership. Leadership and Organization Development Journal, 20(6), 219-299.

Charbonneau, D. (2004). Influence Tactics and Perceptions of Transformational Leadership. Leadership and Organization Development Journal, 25(7), 565-576.

Coad, A., \& Berry, A. (1998). Transformational leadership and learning orientation. Leadership \& Development Journal, 19(3), 164-172. http://dx.doi.org/10.1108/01437739810210211

Crawford, C. (2005). Organizational positional on knowledge management. Journal of knowledge Management, $9(6), 6-16$.

Daft, R. I. (2003). Organization Theory and Design (4th ed.). U.S.A. New York: South-western Publications Co.

Dessler, G. (2008). Human Resource Management (11th ed.). U.S.A: Pearson Prentice Hall.

Gibson, J., Ivancevich, J. M., Donelly, J. H., \& Konopask, R. (2003). Organization: Behavior Structure Process. NewYork: Mc Graw Hill Company Inc.

Hammad, I. (2011). The impact of Transformational Leadership in Change Management-A field Study on Hospital Red Crescent in Damascus. Damascus University Journal Of Science Economic, Legal, 27(4), 383-402.

Harris, A. (2012). Distributed leadership: implications for the role of the principal. British Journal of Management, 31(1), 7-17. http://dx.doi.org/10.1111/j.1467-8551.2006.00480.x

Hellriegel, D., Slocum, J., \& Woodman, R. W. (2001). Organizational Behavior (9th ed.) New York, Ohio: South Western Publishing Co.

Hersey, \& Blanchard, K. (1996). Organizational Behavior: Utilizing Human Resource (6th ed.). New Delhi: Prentice Hall of India.

Hickson, D. J., Wgastley, R. J., \& Wilson, D. C. (1991). Organization as power Research in organizational behavior an annual series \& analytical essays and Critical Reviews. Editors LL Cumming, and BM Straw, 3.

Hughes, R. L., Ginnett, R. C., \& Curphy, G. J. (2009). Leadership: Enhancing The Lessons of Experience. New York: Mc Grew Hill Companies.

Husseini, B. (2010). The Impact of the Transformational and the Transactional Leadership Styles on the Success of the Organizational Changes-An Empirical Study in the General Company for Electrical Industries. Research presented to the Faculty of Pharmacy, University of Baghdad.

Kenny, G., \& Wilson, D. (1984). The Interdepartmental Influence of Managers. Journal of Management Studies, 21(4).

Kezar, A. (2011). Grassroots Leadership: Encounters with Power Dynamics and Oppression. International Journal of Qualitative Studies in Education, 24(4), 471-500. http://dx.doi.org/10.1080/09518398.2010.529848

Khroukh, R. (2010). The Strength of Leadership Tool to Support The Areas of Organizational Change a Prospective Study of The Views of a Sample of Administrative Leaders in some of the Industrial Organizations in Nineveh Province in Iraq. Rafidain Journal, 32(99), 257-274.

Moorhead, G., \& Griffin, R. (1995). Organizational Behavior. Boston, Houghton Mifflin Company.

Robbins, S. (1993). Organizational Behavior Concepts, Controversies, and Applications. New Jersey Prentice Hall.

Silyman, M., \& Azzazi, M. (2010). The Impact of the Dimensions of Transformational Leadership in the Management of Organizational Change-A prospective Study of the Views of A group of Heads of Departments at Waladyha in Mosul/Iraq. The Iinternational Scientific Conference Alsnos VIII, Faculty of Economics and Administrative Sciences, Zaytoonah University.

Tahan, A. (2000). The Impact of Leadership Styles on the Satisfaction of Employees and Administrative Creativity-An Exploratory Study of Joint Stock Companies in Jordan, Master Thesis. Department of Business Administration, Faculty of Economics and Administrative Sciences, Yarmouk University. 
Zearah, F. (2009). Managerial Functions. Jordan, Amman: Alyazori Publishers Co.

\section{Appendix}

\section{Questionnaire}

Please put assign at the right answer

\begin{tabular}{|c|c|c|c|c|c|c|}
\hline Q.No. & Sent. & $\begin{array}{l}\text { Strongly agree } \\
-5-\end{array}$ & $\begin{array}{l}\text { Agree } \\
-4-\end{array}$ & $\begin{array}{l}\text { Don't } \\
\text { know } \\
-3-\end{array}$ & $\begin{array}{l}\text { Disagree } \\
-2-\end{array}$ & $\begin{array}{l}\text { Strongly } \\
\text { disagree } \\
-1-\end{array}$ \\
\hline \multicolumn{7}{|c|}{ The questions relating to the transformational leadership: (The charisma) } \\
\hline 1 & The Director cares of spreading self-confidence. & 5 & 4 & 3 & 2 & 1 \\
\hline 2 & $\begin{array}{l}\text { The Director tries to Development cooperation between us and } \\
\text { participate others to completion the work. }\end{array}$ & & & & & \\
\hline 3 & The Director explains the mission of the company. & & & & & \\
\hline 4 & The Director care with the public interest over personal interest. & & & & & \\
\hline 5 & The Director employs our abilities towards the company vision. & & & & & \\
\hline 6 & $\begin{array}{l}\text { The Director takes into account the values which we believe. } \\
\text { (Inspiration) (Stimulate subordinates) }\end{array}$ & & & & & \\
\hline 7 & The Director cares about the needs of subordinates & & & & & \\
\hline 8 & $\begin{array}{l}\text { The Director commonly hopes in us about working strongly with the } \\
\text { bright future. }\end{array}$ & & & & & \\
\hline 9 & $\begin{array}{l}\text { The Director confirms constantly optimistic about the future of the } \\
\text { company } \\
\text { (Intellectual stimulation) }\end{array}$ & & & & & \\
\hline 10 & The Director pushes us to look at the problems from different aspects. & & & & & \\
\hline 11 & $\begin{array}{l}\text { The Director examines the weaknesses through asking the appropriate } \\
\text { questions. }\end{array}$ & & & & & \\
\hline 12 & $\begin{array}{l}\text { The Director expands our vision to find appropriate solutions to the } \\
\text { problem that we face. } \\
\text { (Individualized considerations) }\end{array}$ & & & & & \\
\hline 13 & The Director contributes in providing training opportunities for us. & & & & & \\
\hline 14 & The Director helps the weaknesses subordinates to do good work. & & & & & \\
\hline 15 & The Director Deals with groups more than deals with individuals. & & & & & \\
\hline \multirow[t]{2}{*}{16} & The Director followed the training result & & & & & \\
\hline & The questions relating to the transactional leadership (Incentive & & & & & \\
\hline 17 & The director understands our desires in light of the specific duties. & & & & & \\
\hline 18 & The director connects the appropriate rewards with the performance. & & & & & \\
\hline 19 & $\begin{array}{l}\text { Subordinates are aware that their incentives combined with the } \\
\text { outstanding work. }\end{array}$ & & & & & \\
\hline 20 & The Director depend on such incentives standards. & & & & & \\
\hline \multirow[t]{2}{*}{21} & $\begin{array}{l}\text { The Director applied the rules and regulations when making decisions } \\
\text { about incentives. }\end{array}$ & & & & & \\
\hline & The questions relating to the transactional leadership (Training) & & & & & \\
\hline 22 & The Director believed that training will reduce the conflicts at work. & & & & & \\
\hline 23 & $\begin{array}{l}\text { Subordinates feel that training is essential to achieve high quality } \\
\text { production. }\end{array}$ & & & & & \\
\hline 24 & $\begin{array}{l}\text { The Director uses consultants when exercising his management of the } \\
\text { sites where there } \\
\text { drawbacks. }\end{array}$ & & & & & \\
\hline \multirow[t]{2}{*}{25} & $\begin{array}{l}\text { The Director focuses on exceptions training programs to eliminate the } \\
\text { work negatives and studied carefully }\end{array}$ & & & & & \\
\hline & $\begin{array}{l}\text { Questions related to the Organizational change: } \\
\text { organizational structure Change: }\end{array}$ & & & & & \\
\hline 26 & $\begin{array}{l}\text { The senior management delegates the necessary authority to lower } \\
\text { levels. }\end{array}$ & & & & & \\
\hline
\end{tabular}


the responsibility for all units of the company are clearly defined

The company's management promotes the informal communication that serves its goals.

The company's management encourages communication between personnel in the same administrative level.

The company's management believes that the formal communication (from top to bottom) is the only way for the exchange of information in the company

Delegations authority contributes the opportunities for increased creativity and innovation.

your duty focus to perform your daily work without submitting proposals for the development of work

the managers defines overall objectives of the company's, and holds specialized units

Develop plans for their implementation

The administrators are flexible in changing the necessary authority.

\section{Changing technology}

The company is interested to improvements its techniques for production..

The new technology that the company introduced lead to increase production

7 the company reconsider the systems and methods of work whenever arises need

The Company used systems and automated equipment in the preparation and storage of information.

The modern mechanization helped in achieving better employee's satisfaction.

The modern mechanization helped the company to improve the quality of the product.

\section{Change of human resources}

The company focuses in their training programs to modify trends workers commensurate with

\section{Goals.}

The company is interested to involve the largest number of employees in its training and development programs.

The company seeks to make the employees working together as groups not individuals.

Determined the functions of the sub-unit will be in the light of the discussions of the group comprising the unit

Itself.

the company's management encouraged the open communication, between all levels of administration and among their subordinates

the company take it $\mathrm{s}$ decisions with consulting specialists who possess the knowledge and information

The training programs cope set up by the company's technological change and change in the tasks

Company.

training programs held by the Company is sufficient to meet the needs of the skills required

49 The changes programs in the company increased the degree of coherence between superiors and subordinates.

Individuals contribute significantly in the decisions in the company.

*source:-alhusayni, bushra, 2010. * Alkhshali, Jarallah, and al-Tamimi, Fadel, 2008. 


\section{Copyrights}

Copyright for this article is retained by the author(s), with first publication rights granted to the journal.

This is an open-access article distributed under the terms and conditions of the Creative Commons Attribution license (http://creativecommons.org/licenses/by/3.0/). 